\title{
PERBEDAAN METODE SCRAMBLE DENGAN METODE WORD SQUARE TERHADAP HASIL BELAJAR SISWA MATA PELAJARAN BAHASA INGGRIS MATERI PARTS OF HUMAN BODY (Studi pada Siswa Kelas III SDIT At-Taufiq Kota Tangerang)
}

\author{
Putri Emma Kurnia Desa, Asih Rosnaningsih, \& Iman Nurjaman \\ putriemmakd@gmail.com, asihrosna@gmail.com \\ Pendidikan Guru Sekolah Dasar \\ Fakultas Keguruan dan Ilmu Pendidikan \\ Universitas Muhammadiyah Tangerang
}

\begin{abstract}
This study aims to determine differences in student learning outcomes in English subjects in two classes, with first experimental class using scramble method and second experimental class using word square method. This type of research is quantitative research with quasi experiment type. In this research the sampling technique using saturated sampling technique. The sample in this research is the students of class IIIA and students of class IIIB at SDIT At-Taufiq Tangerang City. Instruments in this study using objective tests in short form. Based on the calculation using $\mathrm{t}$-test, it is found that $\mathrm{t}$-count $>\mathrm{t}$-table $(3,1>2,011)$ at significant level $\alpha=$ 0,05 . The average score in experimental class I using scramble method is 69.58 and the average score in experiment class II using word square method is 78.2. So the word square method is better than scramble method.
\end{abstract}

Keywords: scramble method, word square method, student learning outcomes

\begin{abstract}
Abstrak: Penelitian ini bertujuan untuk mengetahui perbedaan hasil belajar siswa pada mata pelajaran Bahasa Inggris dalam dua kelas, yaitu kelas pertama adalah kelas eksperimen I diberi perlakuan menggunakan metode scramble dan kelas eksperimen II diberi perlakuan menggunakan metode word square. Jenis penelitian ini adalah penelitian kuantitatif dengan tipe quasi eksperiment. Pada penelitian ini teknik pengambilan sample dilakukan dengan menggunakan teknik sampling jenuh yaitu teknik penentuan pengambilan sampel secara keseluruhan. Pada penelitian ini sampel yang digunakan adalah seluruh siswa kelas III di SDIT At-Taufiq Kota Tangerang yaitu 26 siswa kelas III A dan 26 siswa kelas III B. Instrumen pada penelitian ini menggunakan tes objektif berbentuk isian singkat. Berdasarkan perhitungan menggunakan uji-t didapat bahwa $t_{\text {hitung }}>t_{\text {tabel }}(3,1>2,011)$ pada taraf signifikan $\alpha=0,05$. Rata-rata nilai kelas eksperimen I menggunakan metode scramble sebesar 69,58 dan rata-rata nilai kelas eksperimen II menggunakan metode word square sebesar 78,2. Sehingga metode pembelajaran word square lebih baik dari pada metode scramble.
\end{abstract}

Kata kunci : metode scramble, metode word square, hasil belajar siswa 
Putri, Asih, \& Iman, Perbedaan Metode Scramble dengan...

\section{PENDAHULUAN}

Pembelajaran bahasa merupakan salah satu sarana dalam mencapai tujuan pendidikan sekolah dasar. Pembelajaran bahasa di sekolah dasar mencangkup keseluruhan aspek berbahasa yaitu menyimak, menulis, mendengarkan, dan berbicara. Pembelajaran bahasa diharapkan dapat membantu peserta didik dalam mengenal dirinya, budayanya, dan budaya orang lain. Selain itu Bahasa sebagai sarana komunikasi juga mampu membantu peserta didik dalam mengemukakan gagasan dan perasaan, berpartisipasi dalam masyarakat yang menggunakan bahasa tersebut, dan menemukan serta menggunakan kemampuan analitis dan imajinatif yang ada dalam dirinya.

Bahasa Inggris merupakan bahasa komunikasi yang disepakati bersama secara internasional untuk dijadikan media komunikasi antar negara yang secara geografis berbeda-beda bahasa dan budayanya. Sebagai bahasa internasional, memang sudah sepatutnya pembelajaran bahasa Inggris diajarkan sejak dini. Dalam Permendiknas Republik Indonesia No.22 Tahun 2006, Pendidikan bahasa Inggris di SD/MI dimaksudkan untuk mengembangkan kemampuan berbahasa yang digunakan untuk menyertai tindakan atau language accompanying action. Bahasa Inggris digunakan untuk interaksi dan bersifat "hear and now". Adapun ruang lingkup pembelajaran Bahasa Inggris di sekolah dasar terdiri dari beberapa aspek, yaitu aspek mendengarkan (listening), berbicara (speaking), membaca (reading), dan menulis (writing) .

Pembelajaran bahasa Inggris idealnya disesuaikan dengan kebutuhan siswa dan situasi (kontekstual). Siswa tidak hanya dituntut untuk mampu secara kognitif tetapi kebutuhan perkembangan aspek afektif dan psikomotor mereka harus terpenuhi. Pentingnya pendidikan bahasa Inggris di sekolah dasar saat ini tidak dapat dipungkiri lagi. Sebagaimana diketahui, penguasaan bahasa Inggris saat ini menjadi salah satu kunci meraih keberhasilan dalam kehidupan. Pada era globalisasi saat ini, mayoritas tutorial menggunakan produk teknologi yang dibuat dalam bahasa Inggris. Sehingga mereka yang menguasai bahasa Inggris memiliki kesempatan lebih luas untuk dapat menguasai produk teknologi tersebut. Selain itu, dengan menguasai Bahasa Inggris, dapat memberikan kemudahan dalam mengakses informasi dari berbagai sumber serta mampu meningkatkan nilai (value) seseorang sehingga lebih dihargai dalam lingkup kerja internasional.

Pada saat ini pelajaran bahasa Inggris kurang dikuasai oleh sebagian siswa khususnya pada siswa kelas III SDIT At-Taufiq Kota Tangerang tahun ajaran 2016/2017. Hal ini terlihat dari hasil observasi yang dilakukan oleh peneliti di SDIT AtTaufiq, masih banyak siswa yang mendapat nilai di bawah KKM yang telah ditentukan oleh sekolah.

Berdasarkan observasi, rendahnya hasil belajar bahasa Inggris terlihat dari hasil ulangan siswa yang disebabkan oleh beberapa faktor. Pertama, proses pembelajaran yang monoton. Guru menyampaikan materi hanya dengan mengunakan metode konvensional. Masalah kedua adalah rendahnya penguasaan kosakata siswa, hal ini 
Putri, Asih, \& Iman, Perbedaan Metode Scramble dengan...

dapat dilihat dari hasil ulangan siswa sebelumnya pada materi fruit and vegetables, dari 52 siswa baru 20 siswa yang menguasai kosakata nama-nama buah-buahan dan sayuran dalam bahasa Ingggris. Ketiga, rendahnya motivasi belajar siswa pada pelajaran bahasa Inggris. Hal ini dikarenakan bahasa Inggris di anggap tidak penting dan tidak banyak digunakan di lingkungan sekitar siswa. Keempat, guru menggunakan media yang kurang tepat dalam proses pembelajaran menyebabkan kurangnya minat siswa dalam proses pembelajaran, hal ini berdampak pada rendahnya Hasil belajar Bahasa inggris siswa. Padahal guru sebagai fasilitator, berperan penting dalam memilih strategi mengajar yang sesuai dengan pelajaran bahasa Inggris kepada siswa, mengunakan media yang relevan dan menerapkan berbagai macam metode pembelajaran. Contohnya dengan menggunakan metode scramble dan metode word square.

Metode scramble dan Metode word square merupakan dua metode yang dapat digunakan guru untuk mengembangkan kosa kata dalam bahasa Inggris. Metode scramble adalah cara mengajar yang digunakan guru dalam bentuk acak abjad. Dalam metode scramble siswa di latih ketelitiannya dalam menyusun abjad menjadi sebuah kosa kata dalam Bahasa Inggris. Metode word square adalah metode yang memadukan kemampuan menjawab pertanyaan dengan kejelian dalam mencocokan jawaban pada kotak-kotak jawaban. Metode word square sebenarnya mirip dengan metode permainan, siswa diberikan soal namun dalam bentuk mirip dengan teka-teki silang.

\section{LANDASAN TEORI}

Pengertian belajar dapat ditemukan dalam berbagai sumber. Meskipun kita melihat ada perbedaan-perbedaan di dalam pengertian belajar tersebut dari masingmasing ahli, namun secara prinsip kita menemukan kesamaan-kesamaannya. Menurut M. Taufiq (2013), "Belajar dipahami sebagai suatu proses perubahan perilaku atau peribadi seseorang berdasarkan praktik atau pengalaman tertentu" (h.196).

Adapun menurut Slameto (2013), "Belajar ialah suatu proses usaha yang dilakukan seseorang untuk memperoleh suatu perubahanan tingkah laku yang baru secara keseluruhan, sebagai hasil pengalamannya sendiri dalam interaksi dengan lingkungannnya". Kemudian, menurut Susanto (2012), "Belajar adalah merupakan suatu proses, suatu kegiatan, dan bukan merupakan suatu hasil atau tujuan".

Dari beberapa pendapat ahli di atas juga dapat ditarik kesimpulan bahwa belajar adalah proses untuk menghasilkan perubahan tingkah laku seseorang karena adanya pengalaman, latihan. Usaha ini dilakukan seseorang secara sadar tanpa adanya pemaksaan sehingga dapat menjadikan seseorang dari yang tidak tahu menjadi tahu, tidak mampu menjadi mampu terhadap sesuatu yang belum pernah ditemui atau dipelajarinya.

Dari definisi belajar di atas dapat dipahami bahwa hasil dari belajar itu sendiri adalah adanya perubahan yang terjadi pada diri individu yang sedang belajar. Hasil belajar mempunyai peranan penting dalam proses pembelajaran. Perubahan sebagai 
Putri, Asih, \& Iman, Perbedaan Metode Scramble dengan...

hasil dari belajar ini banyak dikemukakan oleh ahli. Secara sederhana, yang dimaksud dengan hasil belajar menurut Susanto (2012), “Adalah kemampuan yang diperoleh anak setelah melalui kegiatan belajar".

Hal tersebut diperjelas oleh Suprijono (2009), "Hasil belajar merupakan perubahan perilaku secara keseluruhan bukan hanya salah satu aspek potensi kemanusiaan saja". Pendapat ini sejalan dengan Rusman (2015), "Bahwa hasil belajar adalah sejumlah pengalaman yang diperoleh siswa yang mencakup ranah kognitif, afektif, psikomotorik. Hasil belajar tidak hanya berupa konsep teori mata pelajaran saja, tapi juga penguasaan, kebiasaan, presepsi, kesenangan, minat-bakat, penyesuaian social, macam-macam keterampilan, cita-cita, keinginan dan harapan”.

Menurut Djamarah dan Zain (2015), ada beberapa indikator yang menjadi petunjuk bahwa suatu proses belajar mengajar dianggap berhasil adalah sebagai berikut:

1) Daya serap terhadap bahan pengajaran yang diajarkan mencapai prestasi tinggi, baik secara individual maupun kelompok.

2) Perilaku yang digariskan dalam tujuan pengajaran/instruksional khusus (TIK) telah dicapai oleh siswa, baik secara individual maupun kelompok.

Sehubungan dengan hal ini Djamarah dan Zain (2015), Membagi tingkat atau taraf keberhasilan proses mengajar ke dalam beberapa tingkatan. Tingkatan keberhasilan tersebut adalah sebagai berikut :

1) Istimewa/maksimal apabila seluruh bahan pelajaran yang diajarkan itu dapat dikuasai oleh siswa.

2) Baik sekali/optimal apabila sebagian besar $76 \%$ s.d $99 \%$ bahan pelajaran yang diajarkan dapat dikuasai oleh siswa.

3) Baik/minimal apabila bahan pelajaran yang diajarkan hanya $60 \%$ s.d $75 \%$ saja dikuasai oleh siswa.

4) Kurang apabila bahan pelajaran yang diajarkan kurang dari $60 \%$ dikuasai oleh siswa.

Berdasarkan penjelasan di atas dapat diambil kesimpulan bahwa hasil belajar merupakan kemampuan yang didapat oleh individu melalui proses belajar mencangkup ranah kognitif, afektif, psikomotoik. Hasil belajar dalam ranah kognitif biasanya berupa nilai yang diperoleh saat proses belajar mengajar berlangsung. Nilai tersebut berfungsi untuk mengukur tingkat keberhasilan seseorang dalam proses belajar.

Faktor-faktor yang memperngaruhi hasil belajar seperti yang dikemukakan oleh Slameto (2013) terbagi menjadi menjadi dua yaitu : faktor internal dan faktor eksternal. Faktor internal atau faktor yang ada dalam diri individu. Komponen yang terdapat pada faktor internal meliputi : (1) faktor jasmaniah (kesehatan dan cacat tubuh). (2) psikologis (intelegensi, perhatian, minat, bakat, motif, kematangan, faktor kelelahan). Faktor eksternal atau faktor yang ada di luar individu. Komponen yang terdapat pada faktor eksternal meliputi : (1) faktor keluarga (cara orang tua mendidik, relasi antara anggota keluarga, suasana rumah, keadaan ekonomi keluarga, pengertian orang tua, 
Putri, Asih, \& Iman, Perbedaan Metode Scramble dengan...

latar belakang kebudayaan). (2) faktor sekolah (metode mengajar, kurikulum, relasi guru dengan siswa, relasi siswa dengan siswa, disiplin sekolah, alat pelajaran, waktu sekolah, standar pelajaran di atas ukuran, keadaan gedung, metode belajar, tugas rumah). (3) faktor masyarakat (kegiatan siswa dalam masyarakat, mass media, teman bergaul, bentuk kehidupan masyarakat.

Kedua faktor di atas sangat berpengaruh terhadap hasil belajar siswa. Dalam kaitan dengan penelitian ini, metode belajar termasuk dalam faktor eksternal siswa. Penerapan metode pembelajaran yang efektif dan efisien dapat mempengaruhi atau meningkatkan hasil belajar siswa. Metode memiliki peran yang sangat strategis dalam mengajar. Metode berperan sebagai rambu-rambu atau bagaimana memproses pembelajaran sehingga dapat berjalan baik dan sitematis. Karena itu, setiap guru dituntut menguasai berbagai metode dalam rangka memproses pembelajaran efektif, efisien, menyenangkan dan tercapai tujuan pembelajaran yang ditargetkan.

Dalam hal ini Mukrima (2014), "Menyatakan bahwa metode pembelajaran adalah cara atau prosedur yang dipergunakan oleh fasilitator dalam interaksi belajar dengan memperhatikan keseluruhan sistem untuk mencapai suatu tujuan". Pendapat ini sejalan dengan Pribadi (2011) yang menyatakan bahwa, "Metode pembelajaran merupakan cara yang digunakan oleh guru atau instruktur untuk menyampaikan isi atau materi pembelajaran secara spesifik".

Berdasarkan pandangan di atas dapat dipahami bahwa metode merupaka cara penyajian bahan ajar yang di terapkan oleh guru atau seorang pengajar kepada peserta didik dengan harapan pembelajaran tersebut dapat mencapai tujuan sesuai dengan apa yang sudah direncanakan atau di targetkan. Metode yang digunakan dalam melaksanakan aktivitas pembelajaran bervariasi dalam hal interaksi belajar dengan siswa dan juga ukuran kelas.

Menurut Suyatno (2009), scramble merupakan salah satu tipe pembelajaran kooperatife yang disajikan dalam bentuk kartu (Mukrima, 2014). Sedangkan menurut Shoimin (2014), "Scramble merupakan metode pembelajaran yang mengajak siswa untuk menemukan jawaban dan menyelesaikan permasalahan yang ada dengan cara membagikan lembar soal dan lembar jawaban yang disertai dengan alternatif jawaban yang tersedia". Scramble dipakai untuk jenis permainan anak-anak yang merupakan latihan pengembangan dan peningkatan wawasan pemikiran kosakata.

Shoimin (2014) mengungkapkan bahwa, scramble terdiri atas bermacam-macam bentuk, yakni :

1) Scramble kata, yakni sebuah permainan menyusun huruf-huruf yang telah dikacaukan letaknya sehingga membentuk suatu kata tertentu yang bermakna, misalnya : tpeian = petani, kberjae $=$ bekerja.

2) Scramble kalimat, yakni sebuah penyusunan kalimat dari kata-kata yang di acak. Bentuk kalimatnya hendaknya logis, bermakna, tepat dan benar. Contohnya : pergi aku - bus $-\mathrm{ke}-$ naik - bandung $=$ aku pergi ke bandung naik bus. 
Putri, Asih, \& Iman, Perbedaan Metode Scramble dengan...

3) Scramble wacana, yakni sebuah permainan menyusun wacana logis berdasarkan kalimat - kalimat yang di acak. Hasil susunan wacana hendaknya logis dan bermakna.

Menurut pendapat di atas, dapat disimpulkan bahwa metode scramble merupakan sebuah metode permainan acak kata, kalimat atau paragraph, yang digunakan untuk meningkatkan konsentrasi dan kecepatan berpikir siswa, dalam menyelesaikan pertanyaan dan jawaban secara acak yang sudah di sediakan oleh guru. scramble kata digunakan dalam penelitian sebagai metode dalam pembelajaran. Scramble kata diharapkan dapat meningkatkan pengetahuan anak terhadap kosakata bahasa Inggris sehingga mampu meningkatkan hasil belajar siswa.

Menurut Andayani (2015), metode pembelajaran word square merupakan metode pembelajaran yang memadukan kemampuan menjawab pertanyaan dengan kejelian dalam mencocokan jawaban pada kotak-kotak jawaban. Menurut Kurniasih \& Sani (2016), "Metode word square adalah kegiatan belajar mengajar dengan cara guru membagikan lembar kegiatan atau lembar kerja berupa pertanyaan atau kalimat yang perlu dicari jawabannya pada susunan huruf acak pada kolom yang telah disediakan sebagai alat untuk mengukur tingkat pemahaman siswa terhadap materi pelajaran yang telah diajarkan.

Metode pembelajaran ini sesuai untuk semua mata perlajaran. Tinggal bagaimana guru dapat memrogram sejumlah pertanyaan terpilih yang dapat merangsang siswa untuk berpikir efektif. Instrumen utama metode ini adalah lembar kegiatan atau kerja berupa pertanyaan atau kalimat yang perlu dicari jawabannya pada susunan huruf acak pada kolom yang telah di sediakan.

Berdasarkan pendapat di atas, dalam melatih ketelitian dan kejelian siswa dalam menjawab soal, metode word square merupakan metode yang cocok digunakan oleh guru di dalam pembelajaran. karena di dalam metode word square siswa di berikan jawaban yang sudah tersedia namun dengan banyak huruf pengecoh di dalamnya. Metode ini merupakan metode permainan yang juga sangat menyenangkan apabila diterapkan dalam pembelajaran.

\section{METODE PENELITIAN}

Menurut Sugiyono (2016), "Metode penelitian pada dasarnya merupakan cara ilmiah untuk mendapatkan data dengan tujuan dan kegunaan tertentu". Penelitian ini adalah penelitian yang menggunakan metode kuantitatif tipe kuasi eksperimen untuk menguji apakah terdapat pengaruh penerapan metode Scramble dan Metode Word Square terhadap hasil belajar, khusunya dalam pembelajaran bahasa Inggris materi parts of human body siswa kelas III di SDIT At-Taufiq Kota Tangerang.

Sesuai dengan jenis penelitiannya, penelitian ini menggunakan desain quasi eksperimen non eqiuvalent control group design. Karena peneliti menggunakan kelas yang sudah ada jadi tidak membentuk kelas baru. Dalam desain ini terdapat dua 
Putri, Asih, \& Iman, Perbedaan Metode Scramble dengan...

kelompok diberikan perlakuan yaitu kelompok eksperimen I diberi perlakuan menggunakan metode scramble dan kelompok eksperimen II diberi perlakuan menggunakan metode word square. Populasi dalam penelitian ini adalah seluruh siswa kelas III SDIT At-Taufiq Kota Tangerang. Populasi terdiri dari 26 siswa kelas III A dan 26 kelas III B yang berjumlah 52 siswa. Instrumen yang digunakan dalam penelitian ini adalah tes objektif berbentuk isian singkat dengan jumlah soal sebanyak 30 butir soal. Kisi-kisi dan soal dibuat berdsarkan silabus mata pelajaran bahasa Inggris.

Hipotesis dalam penelitian ini adalah :

$\mathrm{H}_{0}$ : Tidak terdapat perbedaan diantara kelas III A yang diajar menggunakan metode scramble dengan kelas III B yang diajar mengunakan metode word square.

$\mathrm{H}_{1}$ : Terdapat perbedaan diantara kelas III A yang diajar menggunakan metode scramble dengan kelas III B yang diajar mengunakan metode word square.

\section{HASIL DAN PEMBAHASAN}

Data penelitian berupa hasil skor siswa baik dari kelas eksperimen I dan eksperimen II kemudian dihitung dengan rumus independent sample t-test menggunakan Microsoft excel 2010. Data dalam tabel statistik digambarkan sebagai berikut :

Tabel 1. Uji t-test data postest kelompok Eksperimen I dan Eksperimen II

\begin{tabular}{|c|c|c|}
\hline \multirow{2}{*}{ Uji t } & $\mathbf{t}_{\text {hitung }}$ & $\mathbf{t}_{\text {tabel }}(\mathbf{5 \%} ; \mathbf{n 1} \mathbf{n} \mathbf{n 2}-\mathbf{2})$ \\
\cline { 2 - 3 } & 3,1 & 2,011 \\
\hline
\end{tabular}

Dari tabel tersebut dapat terlihat hasil pengujian $t_{\text {hitung }}=3,1$ sedangkan $t_{\text {tabel }}=$ 2,011. Karena $t_{\text {hitung }}>t_{\text {tabel }}$ maka $H_{o}$ ditolak, $H_{1}$ diterima. Berdasarkan hasil tersebut ternyata terdapat perbedaan yang signifikan antara kelompok eksperimen I yang mengunakan metode scramble dan kelompok eksperimen II yang menggunakan metode word square. Hal ini juga terlihat dari rata-rata nilai kelas eksperimen I menggunakan metode scramble sebesar 69,58 dan rata-rata nilai kelas eksperimen II menggunakan metode word square sebesar 78,2. Hal ini menunjukan bahwa siswa dengan pembelajaran menggunakan metode word square memberikan hasil yang lebih baik dibandingkan dengan siswa yang menggunakan metode scramble pada siswa kelas III di SDIT At-Taufiq Kota Tangerang tahun ajaran 2016/2017.

\section{SIMPULAN}

Berdasarkan hasil pembahasan, maka penelitian yang dilaksanakan di SDIT AtTaufiq Kota Tangerang dapat disimpulkan bahwa penggunaan metode word square terhadap hasil belajar Bahasa Inggris materi Parts of Human Body lebih memiliki pengaruh dibandingkan dengan menggunakan metode Scramble. Hal ini dapat dilihat berdasarkan perbandingan nilai postest yang dilakukan kedua kelas, yaitu kelas yang menggunakan metode word square memperoleh hasil belajar yang lebih baik dibanding 
Putri, Asih, \& Iman, Perbedaan Metode Scramble dengan...

dengan kelas yang menggunakan metode scramble. Hasil tersebut terbukti berdasarkan analisis stastistik dengan menggunakan uji $t$, bahwa $t_{\text {hitung }}>t_{\text {tabel }}$ yaitu 3,1>2,011, dengan demikian $\mathrm{H}_{0}$ diterima dan $\mathrm{H}_{1}$ ditolak. Berdasarkan hasil belajar yang didapat, disimpulkan bahwa terdapat perbedaan hasil belajar bahasa Inggris pada siswa yang belajar menggunakan metode Word Square dengan metode Scramble.

\section{SARAN}

Berdasarkan hasil penelitian yang telah dilakukan, maka peneliti mengajukan beberapa saran sebagai berikut : 1) Untuk mendapatkan hasil penelitian yang baik, sebaiknya peneliti melakukan observasi terlebih dahulu, untuk mengetahui bagaimana penyampaian guru kepada siswa dalam kegiatan belajar mengajar. 2) Untuk mendapatkan hasil penelitian yang baik, sebaiknya peneliti melakukan observasi terlebih dahulu, untuk mengtahui kemampuan masing-masing siswa. 3) Sebelum melakukan penelitian menggunakan metode scramble dan metode word square, hendaknya guru merencanakan pembelajaran yang akan dilaksanakan dengan baik, sehingga pelaksanaanya dapat berlangsung sesuai dengan yang diharapkan. 4) Bagi peneliti selanjutnya dapat melakukan penelitian yang serupa dengan menyesuaikan materi dan mata pelajaran yang akan digunakan.

\section{DAFTAR RUJUKAN}

Andayani. (2015). Problema dan Aksioma dalam Metodologi Pembelajaran Bahasa Indosesia. Yogyakarta: Deeppublish.

Kurniasih, I \& Sani, B. (2016). Ragam Pengembangan Model Pembelajaran Untuk Peningkatan Proferionalitas Guru. Surabaya: Kata Pena.

Mukrima, S. S. (2014). 53 Metode Belajar dan Pembelajaran. Bandung: Universitas Pendidikan Indonesia.

Peraturan Pemerintahan No 19 Tahun 2005. (Mei 2005) diakses dari http://www.peraturan.go.id

Pribadi, B. A. (2011). Model Assure untuk Mendesain Pembelajaran Sukses. Jakarta: PT. Dian Rakyat.

Rusman. (2015). Pembelajaran Tematik Terpadu. Jakarta: Pt Rajagrafindo Persada.

Shoimin, A. (2014). 68 Model Pembelajaran Inovatif dalam Kurikulum 2013. Depok: Ar - Ruzz Media.

Slameto. (2013). Belajar dan Fakto-fakto yang Mempengaruhi, Edisi Revisi. Jakarta: Pt Rineka Cipta.

Sugiyono. (2016). Metode Penelitian, Kunatitatif, Kualitatif, dan R\&D. Bandung: Alfabeta.

Suprijono, A. (2009). Cooperative Learning Teori dan Aplikasi Pikem. Yogyakarta: Pustaka Pelajar. 
Putri, Asih, \& Iman, Perbedaan Metode Scramble dengan...

Susanto, A. (2012). Teori Belajar \& Pembelajaran di Sekolah Dasar. Jakarta: Kencana Prenada Media Group.

Suyatno, K. K. (2015). English For Young Learning . Jakarta: Bumi Aksara.

Djamarah, S. B. \& Zain, A. (2015). Strategi Belajar Mengajar, Edisi Revisi. Jakarta: Rineka Cipta.

Taufiq, M. (2013). Pengantar Psikologi. Yogyakarta: Smart Writing. 